

\section{The Role Of Cross Selling In SME Banking: An Analysis from Turkey}

\author{
Hande Karadag \\ Vedat Akman
}

\section{Introduction}

SME concept gained popularity in academia and among regulators and practitioners particularly after 1980 's, as the focus in both the developed and developing economies shifted from large corporations to small and medium sized enterprises. Although every economic region or country has its own SME categorization, SMEs and entrepreneurship are accepted "to be a key source of dynamism, innovation and flexibility in advanced industrialized countries, as well as in emerging and developing economies" (OECD, 2006:9).

The role of SME's in social and economic development has been "widely recognized in developed countries as well as developing economies" (OECD,2006:9), particularly after 1980 's. SMEs are called as the "backbone of the European economy" as they constitute $98 \%$ of all enterprises $(20.7$ million businesses) and "account for $67 \%$ of total employment and $58 \%$ of gross value added (GVA) in EU, as of 2012" (EC,2012).

As Ardiç, Mylenko and Saltane stated, SME development is "closely linked with growth" (Ardiç, Mylenko and Saltane, 2011), in their referrals to Beck, et al. (2010) who found "a robust, positive relationship between the relative size of the SME sector and economic growth, even when controlling for other growth determinants" (Ardiç, et al., 2011; Beck, et. al., 2010:187).

Among several problems of SMEs, financial challenges have a unique situation. According to OECD reports, most problems of SMEs have a financial nature (OECD, 2004,2006) as finance " is a key element in determining the growth and survival of SMEs in both developed and developing economies" (Richard and Mori, 2012:2). While there is a wealth of studies on SME finance and particularly SME lending, there have been relatively few academic studies related with the supply side of SME banking (Rocha, et.al, 2011). The leading studies in this field were provided by Beck,et.al $(2008,2009)$, De la Torre, et. al.
(2010) and Rocha et. al. (2011), who addressed the driving factors and challenges in SME banking, together with the evidence on recent trends and developments in the industry. However, the role of non-lending products and services in servicing SMEs has not been studied in depth, up to date.

This paper aims to address this gap in the literature, by analyzing the supply side of non-lending practices to SMEs which is a concept that recently started to attract the interest of SME finance scholars (De la Torre, et. al., 2010). at both international context and in Turkish banking system. Despite the unsaturated nature of SME segment in terms of provision of banking services, the banking system in Turkey is regarded as "advanced" for servicing SMEs and other customers (OECD, 2014). Therefore the analysis is expected to make an important contribution to the SME finance literature by analyzing the development of the concept of cross selling in SME banking and providing valuable information on the cross-selling practices of major banks operating in Turkey, some of which are regarded as 'best practices' by IFC. The study is organized as follows. The first section briefly overviews the SME sector in international and local contexts. In the second part, the emergence and development of cross-selling concept in SME banking is investigated, In third section, major crossselling strategies and practices of market-maker banks in Turkey are analyzed and the last section concludes.

\section{The context of SMEs}

Small and medium-sized enterprises (SMEs) are generally described as "enterprises with a relatively small share of the market, managed by owners or part-owners in a personalized way, and not through the medium of a formalized management structure; and acting as separate entities, in the sense of not forming part of large enterprise or group" (Storey, 1994). Whether an enterprise is an SME or not can vary from one context to another, sometimes varying between institutions of the same country (Özdemir, et.al, 2011).

In Turkey, SMEs are categorized in three groups of micro, small and medium sized enterprises with respect to their employee numbers and annual revenues, as regulated by the Law on SME definition, which came into force on May 18, 2006 and was amended on November 4, 2012 (OECD, 2014). 
Table 1: SME categorization in Turkey

\begin{tabular}{lc}
$\begin{array}{l}\text { Company categories } \\
\text { Annual turnover }\end{array}$ & Number of employees \\
\hline $\begin{array}{l}\text { Medium-sized } \\
\leq \text { USD 17.200.000* }\end{array}$ & $<250$ \\
Small & \\
$\leq$ USD 3.400.000 & $<50$ \\
Micro & $<10$
\end{tabular}

$\leq$ USD 430.000

Source: OECD Scoreboard, 2014, * Figures are converted from TL to USD with the exchange rate of CB of Turkey as of $12 / 15 / 2014$.

SMEs form a large part of economy and are seen as the drivers of socio-economic development. In high income countries SMEs contribute to 50\% of GDP (Ayyagari, et. al., 2007), while two-third of all employment in OECD and emerging markets are supplied by enterprises with less than 250 employees (Stein,et.al, 2013; Ardic, et al, 2012). The importance of SMEs have largely been recognized in the last decades with respect to their contributions to the economy and they are regarded as the "engines of growth" in developing economies, mainly due to the comparably less number of large corporations in these contexts (Narteh, 2013; Floyd \& McManus, 2005). The large share of SMEs in every economy is much owed to their huge numbers, reaching to a height of $99.9 \%$ of all enterprises in many developing countries, including Turkey (Ari, 2013:36).

SMEs are the most important sources of employment in Turkey with 76,7\% share (Sahin \& Dogukanli, 2014), whereas $55 \%$ of total value added and $65 \%$ of total sales in the economy are supplied by SMEs (TOBB, The Union of Turkish Chambers and Exchange Commodities, 2014). As of 2009, there are 2.291.904 SMEs, dominated by the microenterprises with less than 10 employees (OECD, 2014)
Table 2: Distribution of firms in Turkey (2009)

\begin{tabular}{lr} 
Company categories & Number of firms \\
\hline$\underline{\%}$ & \\
$\begin{array}{l}\text { All enterprises } \\
\mathbf{1 0 0}\end{array}$ & $\mathbf{2 . 2 9 4 . 5 5 4}$ \\
$\quad$ SMEs & \\
$99.9 \quad 2.291 .904$ \\
$\begin{array}{l}\text { Medium-sized } \\
0.5\end{array}$ \\
$\begin{array}{l}\text { Small } \\
0.9\end{array}$ \\
$\begin{array}{l}\text { Micro } \\
98.5\end{array}$ \\
\end{tabular}

Source: OECD Scoreboard, 2014

Due to this significant role, the availability and degree of SME financing have been the focus of various academic studies, as it has been underlined as a critical factor in the growth and development of the SMEs (Abdulsaleh \& Worthington, 2013, Norton, 2003; Cook, 2001). As in most developing economies, commercial banks are still the most common sources of SME finance in Turkey (Öndeş \& Güngör, 2013; Şahin, 2011; Çetin, et,al, 2011; Güler, 2010), mainly caused by the underdevelopment of venture capital and credit guarantee systems. However, SMEs face serious collateral, credibility and balance sheet problems which prevent them from utilizing the required amounts of bank loans, particularly when the enterprise is in the startup phase (Uluyol, 2013; Topal, et.al, 2006; Arslan, 2003).

Challenges of SME lending has been the foci of scholarly studies of SME financing in Turkey (Koyuncugil \& Özgülbaş, 2008; Topal, et. al, 2006; Arslan, 2003), to date, leaving the supply side of SME banking largely under investigated. This study therefore aims to address two major research questions, namely "What are the main drivers behind the rising importance of cross-selling activities in SME banking" and "How are cross-selling activities being undertaken in Turkish Banking System?". As lending to SMEs have been the main focus of scholars in SME finance literature, current study is expected to highlight the importance of the recent "non-lending in SME 
banking" concept, by providing theoretical and empirical information on business models, strategies and best practices about the cross-selling of financial products and services to SMEs.

\section{Cross selling in SME banking}

The financial resource constrains of SMEs with respect to larger corporations and the role of banks as major suppliers of financial resources are very well documented in the literature (Narteh; 2013; Abdulsaleh and Worthington, 2013; Roman and Rusu; 2012; Rocha, et. al, 2011; Beck, et. al 2008). As SMEs face several challenges in accessing financial resources which are required for their survival and growth, external financing of SMEs and particularly relationship lending has been in the centre of scholarly analyzing various dimensions of SME financing studies (Hernandez-Canovas, et. al, 2010; De la Torre, 2010; Beck, et. al, 2006; Berger and Udell, 2006; Petersen and Rajan, 1994).

Recently, another stream of research emerged, discussing the financing of SMEs from a "beyond lending" perspective and focusing on the rising interest of banks for offering non-credit financial services to SMEs, which they see as "core and strategic business prospects" (IFC, 2012b; Rocha, et. al 2011; De la Torre, et. al 2010). As Rocha, et.al stated "SME finance is much broader than SME lending, despite the tendency in literature to often equate the two" (Rocha,et.al, 2011). The interviews conducted with the bank managers in Central Europe, South America, Middle East and North Africa by World Bank and IFC researchers show that, as the attractiveness of the SME segment is more recognized, a variety of services and financial products are continuously introduced targeting SMEs, and the banks strategically aim to increase their existing market share and outperform their competitors in SME banking (Abdulsaleh, et al, 2013; Rocha, et.al, 2011; De la Torre, et. al 2010, Beck, et. al, 2008; Stephanou and Rodriguez, 2008).

In the literature, the main factors behind this recent popularity of banking SMEs and particularly non-lending banking product/services are discussed from various aspects. First and foremost, SMEs form the majority of firms in every economy and most enterprises are SMEs (De la Torre, et. al. 2010; Hallberg, 2000). Secondly, the segment of SMEs is perceived as "highly competitive" (De la Torre, 2010) but still "unsaturated" and "promising" by the banks in most developed and developing economies (Beck, et al, 2008). There is a general perception that SMEs are lacking appropriate financing and are in need of external sources of funds provided mainly by the banking system, which is backed up by several studies indicating that the SME segment is "underserved" by the banks (IFC, 2012). The estimates for the growth of bank revenues from SMEs in emerging markets is calculated to be around USD 367 billion in 2015, from a USD 150 billion in 2010 (Stein, et.al., 2013: 11). Thus, motivated by the low profitability of "corporate banking" segment and the intense competition and a comparably more saturated "retail" market, SME customers are now viewed as the new target customer segment by a majority of banks (IFC, 2012b; Roman and Rusu, 2012; De la Torre, et. al 2010). This high focus is reflected in a recent survey conducted by the World Bank with banks from both developing and developed economies, where almost all the interviewees stated ambitious growth targets, such as doubling the volumes of SME banking operations in 1-2 years (De la Torre, 2010).

Besides the potential for gaining new customers who are "in need of receiving special assistance", the most crucial motivation of the banks in this shift of interest is the "perceived profitability" of this segment (Rocha, et.al, 2011; Beck, et al, 2008; De la Torre, et al 2010). This factor is evidenced by the survey of Beck, et. al in 2008 covering 91 banks in 45 countries, in which $81 \%$ of banks from developed countries and $72 \%$ of banks from developing countries indicated the profitability impact as "the most important determinant for their involvement" in SMEs (Beck et al, 2008). However, as every lending incurs the risk of default, the expected profits from SME segment can deteriorate when SME loans are not repaid (Richard and Mori, 2012; Obamuyi, 2007). Studies show that, the default risk of loans is greater for SMEs compared to larger companies (Beck, et. al, 2008). In addition to default risk, SME lending has serious challenges as most SMEs have credibility and collateral problems (OECD, 2014; Beck, et al, 2008; Topal, et.al, 2006; Arslan, 2003) as well as informality and opaqueness issues (De la Torre, 2010). In addition to that, due to the recent crisis, banks are not as willing as the before-crisis period to lend loans to SMEs (Durkin,et.al, 2013).

Combined together, these factors cause the focus of banks to be directed towards non-lending products and services that are suitable for the needs of SMEs, which is considered as a both easier and more profitable concentration area for the banks, as these services and products do not require complex scoring and follow-up procedures as the loan transactions and do not carry the risk of harming the profitability of the banks' as happens in case of defaulted loans. Studies show that, earnings from "other products and services" already amount to $32 \%$ of total revenues in developed countries, illustrating the importance of non- 
lending activities for the banking system, and placing cross-selling "at the heart of banks' business strategy" (De la Torre, 2010).

The provision of multiple non-lending services and products to SMEs not only has a positive impact on "return on limited capital" of banks, but it also makes possible for the banks to deepen their relationships with their SME customers. Research shows that becoming the main bank of a customer increases the profitability per customer three times more than that of the non-main bank customer segments (IFC, 2012), which can only be attained through selling various financial products to the same client. In addition to that, cross selling strengthens the bond between the bank and the SME, which in turn increases the level of customer loyalty and facilitates the future lending activities (IFC, 2012; De la Torre, 2010).

As stated by De la Torre, et. al (2010) another strategic advantage of cross selling from the banks' perspective is enabling banks' access to SME employees and employees' families. Through their technological infrastructure, banks are able to design payroll systems which opens new and utterly useful channels for gaining retail customers and selling of retail banking products (e.g. credit cards) to these newly acquired customers.

IFC reports state that, best practices of cross selling in SME banking has eight common characteristics, as:

- customer education

- product bundling,

- product portfolio management,

- cross-unit sales and referrals,

- event-driven marketing,

- coverage model and account management,

- optimized pricing strategies,

- $\quad$ loyalty management (IFC, 2012:30).

Through educating customers, banks are able to position themselves as the main financial service providers of their customers, apart from the increased cross-selling opportunities caused by the creation of demand.

Product and service bundling, which can be described as “ a combination of products and services are offered in one package, typically at a discount with respect to the combined price of individual elements" is another best practice in SME banking cross selling activities (IFC, 2012:32). While this method has the clear advantage of "locking in clients", the pricing strategy has a crucial importance as a mispriced bundle can destroy the existing profits of the bank.

An efficient management of the product/service portfolio is another success factor for cross selling. The number of a typical portfolio can include up to 60 different products/services, however too many products have the risks of being unmanageable by the relationship managers in the branches and most of these services/products have no marginal contribution to profitability. Thus, the best practices in cross-selling of SME banking products/services are found to be eliminating the $60 \%$ of their product/service portfolios with profit contributions close to zero (IFC, 2012:35).

New business models for increased cross selling

Segregating customer portfolio in terms of corporate, SME and retail customer bases is becoming a common practice both in developed and developing economies (IFC, 2012b; Rocha, et.al, 2011; De la Torre, 2010; Beck, et, al, 2008). This "decentralization of the sales function" model basically involves employing specialized SME relationship managers in branches, therefore using the branch network as distribution channels for selling of financial products and services designed for SMEs (IFC,2012b; Rocha, et.al, 2011, De la Torre, 2010).

In SME banking, large banks have several advantages in using sophisticated business models for rendering new products/services to SMEs, having more advanced IT systems, technical know-how and diverse service platforms, with respect to their smaller competitors (De la Torre, 2010). Additionally, large banks are able to connect their SME customers with corporate and upper-mass segments, or even gain new SMEs through their interrelationships. For example, with the information provided by their corporate customers, banks can set up IT based systems for linking the accounts of their corporate and retail banking customers to SMEs, such as automatic payment systems for the energy expenses of SMEs, which facilitates SMEs' payments to their suppliers and enables the banks to reach a large number of new SMEs. Like this case of payment/collections systems, much of these advanced business models are planned for meeting the demands of SMEs, who lack the facilities to efficiently manage and follow-up specific financial transactions, such as payment of wages or foreign trade activities. Thus, banks highly utilize these activities outsourced to them by the SMEs and increase the cross selling of their various feebased services and products. As the requirements for customization of these products and services for SMEs is low, they can be sold to every SME customer as mass products in the branches, which is a highly profitable and a 
risk-adverse way of rendering financial services, while the SMEs perceive these products/services as tailored according to their specific needs. Technological improvements such as online banking also help fasten the cross selling processes to SMEs, as well as enabling the introduction of new products and services.

Typically, the design and strategic management of cross selling of the the wide array of services and products are carried out by the headquarters, and through their branch networks and specialized SME personnel, these are offered to SMEs, with the end goal of increasing the number of products/serviced used per an SME. The number of products/services used by an SME is a common measure for improving the profitability of SME segment in banks, and a minimum of 5 products/services is found to be necessary for an SME to pass the optimum point of becoming profitable. These products/services can range from checking/savings accounts and company credit cards, to insurance products and payment/receivable systems (such as tax payments), depending on the infrastructural facilities of the banks.

\section{Cross selling to SMEs in Turkish Banking System}

In Turkey, there are 49 banks operating with 12.033 branches as of March, 2014 (Banking Regulation and Supervision Agency of Turkey, 2014).

Table 3: Ranking of Turkish banks

\begin{tabular}{|c|c|c|c|c|c|c|c|c|c|c|}
\hline & & Top 10 Bank & is in Tur & rkey Accordi & ding to As & $\operatorname{sets}(31)$ & $103 / 201$ & & & \\
\hline (million L & & & & & & & & & & \\
\hline & Banka & $\begin{array}{c}\text { Year d } \\
\text { Establishment }\end{array}$ & $\begin{array}{l}\text { Total } \\
\text { Assets }\end{array}$ & $\begin{array}{c}\text { Total loans } \\
\text { and } \\
\text { Receivables }\end{array}$ & $\begin{array}{c}\text { Total } \\
\text { Deposits }\end{array}$ & $\begin{array}{l}\text { Total } \\
\text { Equity }\end{array}$ & $\begin{array}{l}\text { Paid } \\
\text { Capital }\end{array}$ & NetPL & \begin{tabular}{|c} 
No.of \\
Branches
\end{tabular} & $\begin{array}{l}\text { Na.d } \\
\text { Employes }\end{array}$ \\
\hline & 1. ĖşBankas A.S. & 1924 & 100,035 & 61316 & 58,502 & 12,978 & 2,480 & 575 & 1,265 & 24,30 \\
\hline & T.CZirat Bankas A.S. & 1863 & 93,325 & 42,957 & 66,557 & 9,883 & 1,380 & 506 & 1,528 & 23,33 \\
\hline & I, Granti Bankas ASS. & 1946 & 92,309 & 53295 & 52,603 & 12,229 & 2,320 & 565 & 943 & 17,98 \\
\hline & Akbank T.AS. & 1948 & 86,350 & 50,571 & 48,232 & 11,992 & 2,200 & 488 & 966 & 16,42 \\
\hline & Yapı ve Kreä Bankas A.S & 1944 & 69,834 & 43,182 & 39,332 & 9,494 & 2,400 & 303 & 929 & 14,73 \\
\hline & T. Halk Balkas AS. & 1938 & 61,518 & 38,112 & 4,428 & 7,164 & 690 & 400 & 846 & 14,72 \\
\hline & T. Vastlar Bankasi T.A.0. & 1954 & 58,999 & 38,534 & 36,159 & 6,728 & 1,380 & 293 & 74 & 13,51 \\
\hline & Finans Barkis AȘ. & 1987 & 29,990 & 20,859 & 18,440 & 4,092 & 1,417 & 153 & 592 & 12,52 \\
\hline & Tưrk Ekonomi Bankas AS. & 1927 & 26,019 & 17,839 & 17,022 & 2,731 & 1,217 & 99 & 529 & 9,75 \\
\hline & Denizbank A.S. & 1997 & 25,718 & 16,709 & 15,840 & 2,821 & 395 & 135 & 623 & 10,68 \\
\hline
\end{tabular}

Source: The Banks Association of Turkey (2014), * Figures are converted from TL to USD with the exchange rates of
CB of Turkey, as of 31/03/2013 and 01/01/201331/03/2013 average (for net $\mathrm{P} / \mathrm{L}$ values).

Servicing SMEs is one of the main strategic priorities of all banks in the sector, which is most clearly represented by the fast increase in SME loans.

Table 4: The development of SME loans in Turkish Banking System

(millions USD)

\begin{tabular}{|l|l|l|}
\hline & SME Loans & growth (\%) \\
\hline Dec-09 & 55.880 & \\
\hline Dec-10 & 81.150 & 47,3 \\
\hline Dec-11 & 85.810 & 4,9 \\
\hline Dec-12 & 111.460 & 29,1 \\
\hline Dec-13 & 127.420 & 14,4 \\
\hline Mar-14 & 132.490 & 3,9 \\
\hline
\end{tabular}

Source: Banking Regulation and Supervision Agency of Turkey website, 2014, *Figures are converted from TL to USD with the exchange rates of $\mathrm{CB}$ of Turkey.

Between 2007-2012, the loans lent to SMEs by the banks rose at the rate of $156 \%$, which is the greatest expansion in SME lending among OECD countries (OECD, 2014). As shown in Table 2, the SME loans increased from USD 111,4 million at December 2012 to USD 127,4 million at December 2013 and USD 132,5 million USD at March, 2014 (Banking Regulation and Supervision Agency of Turkey 2014).

Despite the significant developments in SME lending volumes, the SME segment still "remains underserved, and constrained access to finance is perceived as the single largest obstacle to growth by SMEs" (OPIC, 2014). The SME specific lending problems of informality, opaqueness and credibility, combined with macroeconomic instabilities form the major obstacles to supplying loans to SMEs by the banks (Şahin, 2011). These challenges lead the banks to rely more heavily on fee based financial products and services in SME banking, as in case of most developing economies. The large size of the SME segment with approximately 3.2 million SMEs as well as 3 million farmers and agricultural producers, of which a large portion is still under banked, is another factor behind the recent concentration and increasing product/service sales activities of banks to SME segment (Yapi Kredi, 2013). 
In Turkey, the worldwide trend of setting up separate units for serving the SME segment, led by the multinational banks operating in local markets, is becoming a common practice. In this business model, the sales function of the financial products and services are decentralized and delegated to the branches, while loan approval procedures, risk management and recovery of defaulted loans are kept centralized (Beck, et. al, 2008). The business models and major non-lending products/service practices offered to SMEs by the leading banks in Turkey can be briefed as follows:

Is Bankasi A.S: İş Bankasi is Turkey's largest bank of Turkey, with respect to total assets, total loans and shareholders' equity. It is also the leader in deposits among privately-owned banks. The bank manages its SME banking operations under commercial banking and its most differentiated service to SMEs in the market is the website IsteKobi (SMEs in Is), followed by 56.000 SMEs in 2013. The bank uses its widespread branch network, consisting of 1.265 branches and employees customer relations managers and customer representatives for providing financial services to SMEs (Is Bankasi, 2013).

Ziraat Bankasi A.S.: As the largest state-owned bank in Turkey established with the mission of supporting the agricultural sector, the main strategy of Ziraat Bankasi for servicing SMEs is to provide loans to SMEs with facilitated credit conditions, particularly through its World Bank and EIB (European Investment Bank) partnerships. In 2012 and 2013, the Bank completed its customer and branch segmentation efforts and the moved to portfolio management business model and also expanded its number of Entrepreneurial Banking branches (Ziraat Bank, 2013).

Garanti Bankasi A.S.: Garanti Bankasi is the second largest private bank in Turkey, with consolidated assets of US\$ 104.5 billion as of December 31, 2013. Having reorganized the head office and branches for the SMEs, the Bank has a separate SME department in Headquarters and pursues the strategy of being the "Bank of SMEs" and the "Future Guarantee of Tradesmen. For increasing its cross-selling activities, the bank has the goals of:

- providing support the digital transformation of SMEs so as to help them use IT technologies effectively,

- $\quad$ design solutions for the needs of SMEs in various areas by establishing partnerships and collaborations with powerful brands and institutions,
- offer diverse financing options to new entrepreneurs in need of fast and simple access to financial resources, and act as their solution partner on the basis of strong collaborations,

- carry out agricultural banking focused on sector/product/region,

- allow the product suppliers and firms taking place in the agricultural value chain to work with models that fit the relative cycles of sub-sectors in line with the demands and requirements that differ regionally (Garanti Bankasi, 2013).

Akbank T.A.S.: In the ranking of private banks, Akbank has the third place in the sector in terms of its assets, as of December, 2013 (TBB, 2013). The Bank conducts its SME banking activities with its 985 branches and 23 regional directorates across Turkey. The main SME segment strategy of the Bank is the developing of tailor made products, such as Axess SME Card, Agriculture Card, Axess Business and checkbook that could be requested with an SMS, and 'SME Tariffs (KOTA)' product that allows SMEs to choose the bundled product that best suits their banking transaction mix by paying a single fixed fee. In 2013, the Bank also revised its EkoPOS product, which is the first installment POS in the sector. Also, promotional campaigns offering complimentary devices were ran by the Bank for customers who are obliged to use cash register POS with recently changed regulations. The non-financial services of Akbank SME Banking include the "Craftsmen Fraternity" launched to serve artisans and the "SME Line" which is as a specific online service designed for meeting the information and service requests of SMEs and is available to all enterprises whether they are the Bank's customers or not (Akbank, 2013).

Yapi ve Kredi Bankasi A.S. : Yap1 Kredi is the 4th largest private bank in Turkey with total assets of TL 182.0 billion and ranks 5th in total cash loans with 9.9\% market share and 6th in total deposits with $9.8 \%$ market share. Yapi Kredi's strategic business unit based service model consists of three major segments of retail banking (including individual, SME and card payment systems), corporate \& commercial banking and private banking and wealth management. The Bank serves its 911.000 SME customers in 842 branches with 1.583 relationship managers and has a wide range of product/service offerings, including product bundles, POS and merchant services, cash management products, investment products and commercial purchasing cards. Yapi Kredi was the first bank in the sector to introduce product bundles with a variety of basic banking products in a single package and these products are used by 155.000 SME customers as of December 2013, with the 
new 51.000 customers gained in the last year. The Bank's major SME strategy in SME banking is new customer acquisition, supported by SME Hunters, a special team formed in 2012 with the sole purpose of acquiring new customers (Yapi Kredi, 2013).

Turk Ekonomi Bankasi A.S.(TEB): By IFC (International Finance Cooperation), TEB was awarded as "One of the Best Three Banks in the World" in the category of "Offering Non-Financial Services to SMEs" in 2012. With a strong SME focus, TEB increased its SME customer base from 9.481 SMEs in 2005 to 657.335 SMEs in 2011. The Bank offers several financial products and services tailored specifically for SMEs, including bundled SME Support Packages, which are determined by the analysis of most frequently performed transactions of the SMEs in the Bank and are categorized as 'Support on Credit Package', 'Daily Support Package' and 'Virtual Support Package'. The sales activities of SME products and services are conducted through various distribution channels such as branches and SME Support Line. The Bank also provides several award winning non-financial SME services such as SME Club, SME Academy, SME Meetings, Agriculture Meetings and SME TV. In 2013, a separate Enterprise Banking unit inside the SME Banking department and a consultancy center called as 'Enterprise House' were set up for exclusively serving to 'entrepreneurs' (TEB, 2013).

As this review illustrates, while there is a clear and strong focus of all banks for the cross selling activities to SMEs, field applications can show variances between banks. Most of the market maker banks currently run their SME banking operations through separate SME departments in their headquarters, where the SME strategies and products are developed. While some banks are more aggressive to offer the contemporary 'product bundles' to their SME customers, others continue to serve their financial services as 'separate' products or services, where SMEs pay a fee for each product or service. The most common channels of sales activities are the wide branch network and specialized SME relationship managers, however almost every bank has also active online SME services. Some banks, such as Garanti, are more technology oriented in new product developments, while others like TEB focus on nonfinancial services for gaining new customers and deepening their existing relationships with the SME segment.

\section{CONCLUSION}

Banking SMEs is a topic which has been attracting the interest of academics and practitioners particularly within the last decades. As banks are traditionally regarded as the major funding sources of SMEs, the drivers and challenges of SME lending has been the main focus of academic studies, to date. However, with the recent developments in the industry, SME banking is shifting to a non-lending dimension, mainly due to the challenges and risks related with SME loans. Thus, cross-selling of non-lending products is perceived as a major strategy for increased profitability by a majority of banks, which also indicates a strong need for scholarly interest to this field.

In this analysis, we aimed to focus on the approach of banks operating in Turkey to this recent phenomenon, by investigating their business models, strategies and implementation practices with respect to increasing the sales volumes of non-lending products/services to SME customers. The results of our analysis showed that, in Turkey, banks serving SMEs have high expectations about the fast growth of the market and have carefully been following (and sometimes launching) best practices for increasing the number of products/services sold to an SME, such as decentralizing the sales activities to branches, deepening and strengthening customer relationships through non-financial services, evaluating the efficiency of customer and product portfolios and focusing on development of products for meeting the specific requirements of the SMEs.

As this research area is newly developing, further studies can focus on the financial or overall performance results of the pursued strategies of the banks or cross-country evaluations, where the cross selling activities of banking industries in selected countries can be compared with each other.

\section{REFERENCES:}

Abdulsaleh, M.A., and Worthington, C.A.(2013). Small and Medium Sized 
Enterprises Financing: A Review of

Literature. International Journal of

Business and Management. 8(14): 35-

43.

Akbank T.A.S. Annual Report, (2013). http:/

/www. akbank. com/ Documents

/AKBANK

_AN

NUAL_REPORT_2013.pdf

Ardic, O.; Mylenko, N. and Saltane, V. (2011).

Small and Medium Enterprises A

Cross-Country Analysis with a New

Data Set. World Bank Policy Research

Paper 5538.

Arı, A. (2013). KOBİ'ler, Esnaf ve Sanatkarlar

Özel İhtisas Komisyonu Raporu.

Trakya Kalkınma Ajansı.

http://www.trakya2023.com/uploads/do

cs/09072013yl8AAu.pdf.

Arslan, Ö. (2003). Küçük ve orta ölçekli işletmelerde çalışma sermayesi ve bazı finansal yönetim uygulamaları. Cumhuriyet Üniversitesi, İ.İ.B.F. Dergisi, 4 (1): 121-135.

Ayyagari, M., Beck, T., \& Demirguc-Kunt, A. (2007). Small and medium enterprises across the globe. Small Business Economics, 29(4), 415-434.
Beck, T. (2010). SME Finance: What Have We Learned and What Do We Need to Learn? The Financial Development Report: 187-195.

Berger, A. N., \& Udell, G. F. (2006). A more complete conceptual framework for SME finance. Journal of Banking \& Finance, 30(11), 2945-2966.

BDDK, Banking Regulation and Supervision Agency of Turkey, (2014). http://www.bddk.org.tr/ WebSitesi/english/Statistical_Data/Mo nthly_Reports/Monthly_Reports.aspx.

Cook, P. (2001). Finance and small and medium-sized enterprise in developing countries. Journal of Developmental Entrepreneurship, 6(1), 17-40.

Çetin, A. C.; Akyüz, Y; \& Genç E. (2011). Küresel kriz sürecinde imalat sanayi işletmelerinin finansal sorunlarının değerlendirilmesi Uşak ili orneği. Journal of Suleyman Demirel University Institute of Social Sciences, 1(13): 55-68.

De la Torre, A., Martínez Pería, M. S., \& Schmukler, S. L. (2010). Bank involvement with SMEs: beyond 
relationship lending. Journal of

Banking \& Finance, 34(9), 2280-2293.

Durkin, M., McGowan, P., \& Babb, C. (2013). Banking support for entrepreneurial new venturers: Toward greater mutual understanding. Journal of Small Business and Enterprise Development, 20(2), 420-433.

European Commission. (2012). Annual Report on Small and Medium-sized Enterprises in the EU: EU SMEs in 2012: At the crossroads.

Floyd, D., \& McManus, J. (2005). The role of SMEs in improving the competitive position of the European Union. European Business Review, 17(2), 144150.

Güler, S. (2010). İstanbul Menkul Kiymetler Borsası'na (İMBK) kayıtlı küçük ve orta büyüklükteki işletmelerin (KOBİ) sermaye yapıları uzerine bir uygulama. Suleyman Demirel University, The Journal of Faculty of Economics and Administrative Sciences, 15(3): 353371.

Hallberg, K. (2000). A market-oriented strategy for small and medium scale enterprises (Vol. 63). World Bank

Publications.

Hernández-Cánovas, G., \& Martínez-Solano, P. (2010). Relationship lending and SME financing in the continental European bank-based system. Small Business Economics, 34(4), 465-482.

IFC, International Finance Corporation (2012).

Customer Management in SME

Banking: A Best-in-Class Guide. IFC

Publications.

IFC,International Finance Corporation (2012b). Why Banks in Emerging Markets Are Increasingly Providing Non-financial Services to Small and Medium Enterprises. IFC Publications.

Mori, N., Richard, E., Isaack, A., \& Olomi, D. (2009). Access to finance for SMEs in Tanzania. African Entrepreneurship and Small Business Development: Context and Process, 1.

Narteh, B. (2013). SME bank selection and patronage behaviour in the Ghanaian banking industry. Management Research Review, 36(11), 1061-1080.

Norton, A. (2003), “'Basel 2 - SME 0', Another tricky hurdle for business?", Credit Management, March, p. 40. 
OECD, Organisation for Economic Cooperation and Development (2014). Financing SMEs and Entrepreneurs 2014: An OECD Scoreboard, OECD Publishing.

OECD, Organisation for Economic Cooperation and Development (2005). OECD Factbook: Economic, Environmental and Social Statistics, OECD.

OECD, Organisation for Economic Cooperation and Development (2006). The SME Financing Gap (Vol. I): Theory and Evidence. OECD

OPIC, Overseas Private Investment Corporation, (2014). http://www.opic.gov/projects/turkiyegaranti-bankasi.

Özdemir, S.; Ersöz, H. Y.; and Sarığlu, H. İ. (2011). Küçük Girişimciliğin Artan Önemi ve KOBİlerin Türkiye Ekonomisindeki Yeri. Sosyal Siyaset Konferansları Dergisi, 12(3): 67-83

Ondes, T. \& Gungor, N. (2013). Kobi'lerin finansmani Erzurum Organize Sanayi Bolgesinde bir arastirma. Ataturk University Journal of Economics and Admistrative Sciences, 27 (1).
Petersen, M. A., \& Rajan, R. G. (1994). The benefits of lending relationships: Evidence from small business data. The journal of Finance, 49(1), 3-37.

Rocha, R. D. R., Farazi, S., Khouri, R., \& Pearce, D. (2011). The status of bank lending to SMES in the Middle East and North Africa region: the results of a joint survey of the Union of Arab Bank and the World Bank. World Bank Policy Research Working Paper Series, Vol.

Roman, A., \& Rusu, V. D. (2012). The Access Of Small And Medium Size Enterprises To Banking Financing And Current Challanges: The Case Of Eu Countries. Annales Universitatis Apulensis Series Oeconomica, 2(14).

Sahin, A., \& Dogukanli, H. (2014). The Impact of Foreign Bank Entry on SME Loans: An Investigation for Turkey. Journal of BRSA Banking and Financial Markets, 8(2), 39-73.

Stein, P., Ardic, O. and Hommes, M. (2013) Closing the Credit Gap for Formal and Informal Micro, Small, and Medium Enterprises. International Finance Corporation, World Bank Group, Washington DC. 
Stephanou, C., \& Rodriguez, C. (2008). Bank financing to small and medium-sized enterprises (SMEs) in Colombia.

Storey, D. J. (1994) Understanding the Small Business Sector. Cengage Learning EMEA.

T. Garanti Bankasi A.S. Annual Report, (2013). http://www.garanti.com.tr /en/ our _ company /investor_ relations /financials_and_presentations/annual_r eports.page

T. Is Bankasi A.S. Annual Report, (2013). http://www.isbank.com.tr/EN/aboutisbank/investor-relations/publicationsand-results/annualreports/Documents/İşbank\%202013\%2 OIng.PDF.

TBB, The Banks Association of Turkey, (2014). http://www.tbb.org.tr/tr/bankave-sektor-bilgileri /istatistikiraporlar/Aktif_Buyukluklerine_Gore_B anka_Siralamasi/1258

TOBB, The Union of Turkish Chambers and Exchange Commodities (2014). http://kobi .org.tr /index. php /tanimi/stats.

TEB, Turk Ekonomi Bankasi A.S. Annual
/Document /yi/ faal_rapor/2013Faaliyet/TEB_ANNUA L\%20REPORT\%202013.pdf

Topal, Y.; Erkan, M.; Elitaş, C. (2006). Küçük ve orta boy işletmelerin finansal yönetim uygulamalar1: Afyonkarahisar orneği, Süleyman Demirel Üniversitesi, İ.İ.B.F. Dergisi, 11(1): 281-298.

Yapi ve Kredi Bankasi A.S. Annual Report, (2013). http://www. yapikredi. com.tr/en/ investor relations/financials.aspx?selectTab=ann uals

T.C. Ziraat Bankasi A.S. Annual Report, (2013). http://www. ziraat.com.tr /en/InvestorRelations /Financials/Pages/AnnualReports.aspx

Report, (2013). http://www .teb. com.tr 